\title{
Front Matter: Volume 11664
}

, "Front Matter: Volume 11664," Proc. SPIE 11664, Solid State Lasers XXX: Technology and Devices, 1166401 (21 April 2021); doi: 10.1117/12.2596777

SPIE. Event: SPIE LASE, 2021, Online Only 


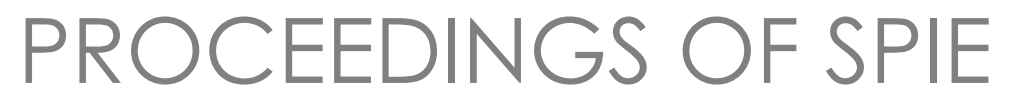

\section{Solid State Lasers XXX: Technology and Devices}

W. Andrew Clarkson

Ramesh K. Shori

Editors

6-11 March 2021

Online Only, United States

Sponsored and Published by

SPIE 
The papers in this volume were part of the technical conference cited on the cover and title page. Papers were selected and subject to review by the editors and conference program committee. Some conference presentations may not be available for publication. Additional papers and presentation recordings may be available online in the SPIE Digital Library at SPIEDigitalLibrary.org.

The papers reflect the work and thoughts of the authors and are published herein as submitted. The publisher is not responsible for the validity of the information or for any outcomes resulting from reliance thereon.

Please use the following format to cite material from these proceedings:

Author(s), "Title of Paper," in Solid State Lasers XXX: Technology and Devices, edited by W. Andrew Clarkson, Ramesh K. Shori, Proceedings of SPIE Vol. 11664 (SPIE, Bellingham, WA, 2021) Seven-digit Article CID Number.

ISSN: 0277-786X

ISSN: 1996-756X (electronic)

ISBN: 9781510641631

ISBN: 9781510641648 (electronic)

Published by

SPIE

P.O. Box 10, Bellingham, Washington 98227-0010 USA

Telephone +1 3606763290 (Pacific Time) · Fax +1 3606471445

SPIE.org

Copyright (c) 2021, Society of Photo-Optical Instrumentation Engineers.

Copying of material in this book for internal or personal use, or for the internal or personal use of specific clients, beyond the fair use provisions granted by the U.S. Copyright Law is authorized by SPIE subject to payment of copying fees. The Transactional Reporting Service base fee for this volume is $\$ 21.00$ per article (or portion thereof), which should be paid directly to the Copyright Clearance Center (CCC), 222 Rosewood Drive, Danvers, MA 01923. Payment may also be made electronically through CCC Online at copyright.com. Other copying for republication, resale, advertising or promotion, or any form of systematic or multiple reproduction of any material in this book is prohibited except with permission in writing from the publisher. The CCC fee code is $0277-$ $786 \mathrm{X} / 21 / \$ 21.00$.

Printed in the United States of America by Curran Associates, Inc., under license from SPIE.

Publication of record for individual papers is online in the SPIE Digital Library.

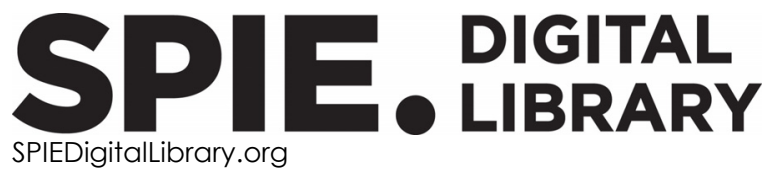

Paper Numbering: Proceedings of SPIE follow an e-First publication model. A unique citation identifier (CID) number is assigned to each article at the time of publication. Utilization of CIDs allows articles to be fully citable as soon as they are published online, and connects the same identifier to all online and print versions of the publication. SPIE uses a seven-digit CID article numbering system structured as follows:

- The first five digits correspond to the SPIE volume number.

- The last two digits indicate publication order within the volume using a Base 36 numbering system employing both numerals and letters. These two-number sets start with $00,01,02,03,04$, 05, 06, 07, 08, 09, OA, OB ... 0Z, followed by 10-1Z, 20-2Z, etc. The CID Number appears on each page of the manuscript. 


\section{Contents}

\section{EYE-SAFE AND MID-IR LASERS}

1166406 Eye-safe laser illuminators for long-reach Lidar and gated imaging in harsh weather conditions [11664-1]

$1166407 \quad 2 \mu \mathrm{m}$ Tm:YAG laser with pulse-on-demand operation [11664-2]

11664 OA Coupled cavity 13mJ mid-IR pulsed source using a passively Q-switched Nd:YAG laserand KTA OPO followed by a CSP OPA [11664-5]

11664 OB Passively Q-switc hed Tm:YLF laser generating 15 mJ , 500 kW peak power pulses [11664-6]

11664 OF State-of-the-art single crystal sapphire and YAG fibers for passive mid-IR delivery systems (Invited Paper) [11664-10]

\section{UV-VISIBIE LASERS}

11664 ol Progress in green disk laser development for industrial high powerapplications [11664-13]

11664 0] 50W 343nm frequency-tripled operation of a high-repetition-rate, novel architecture, femtosec ond thin slab amplifier [11664-14]

\section{PULSED AND ULTRAFASTLASERS}

11664 OL Life-time evaluation of monolithic >MW peak power Nd:YAG/Cr.YAG ceramic mic rochip lasers [11664-16]

11664 OM High-power high-brightness disk lasers for advanced applications (Invited Paper) [11664-17]

11664 ON VIS-to-NIR multiple output sub-TW class modular laser based on OPC PA and TSRCPA [11664-18]

11664 0T Multi-TW, sub 33-fs fiber laserseeded Ti:Sa amplifier [11664-24]

NOVEL LASER CONCEPIS

11664 OY $\quad 1.064 \mu \mathrm{m}$ CW stable single frequency emission and noise reduction based on a monolithic cavity [11664-29] 


\section{POSTER SESSION}

1166410 Low temperature gain-switched operation of non-cubic $\mathrm{Cr}^{2+}, \mathrm{Fe}^{2+}: \mathbf{Z n}_{1-x} \mathrm{Mg}_{\mathrm{x}} \mathrm{Se}(\mathrm{x} \approx 0.2$ and $x \approx 0.3$ ) single crystals in mid-infrared under different excitation wavelengths [11664-31]

1166411 GALACTC: high performance alexandrite crystals and coatings for high power space applications [11664-32]

1166413 Holmium doping concentration influence on Ho:YAG crystal spectroscopic properties [11664-34]

1166414 Tm:YAP mic roc hip laser under 1700 nm and 790 nm diode pumping [11664-35]

1166415 Modeling of themal lensing in a microchip Nd:YAG laser for high power operation [11664-36]

1166416 Efficient multi-watt CWYb:CaF2 laser[11664-37]

1166417 A simple approach to estimate themal lensing in Nd-ion doped vanadate laser crystals [11664-38]

1166419 Conical refraction Nd:CALGO laser with dual-wavelength output [11664-40]

11664 1A Diode-pumped Yb:YAP laser with dual-wavelength output [11664-41]

11664 1B Dual-wavelength Nd:YVO laser with two-crystal geometry [11664-42] 